\title{
Integrative Assembly of Heteroleptic Tetrahedra Controlled by Backbone Steric Bulk
}

\author{
Jacopo Tessarolo, Haeri Lee, Eri Sakuda, Keisuke Umakoshi, and Guido H. Clever* \\ Cite This: J. Am. Chem. Soc. 2021, 143, 6339-6344 \\ Read Online
}

ACCESS |

Lلll Metrics \& More

Article Recommendations

Supporting Information

ABSTRACT: A bent fluorenone-based dipyridyl ligand $\mathrm{L}^{\mathrm{A}}$ reacts with $\mathrm{Pd}^{\mathrm{II}}$ cations to a solvent-dependent dynamic library of $\left[\mathrm{Pd}_{n} \mathrm{~L}_{2 n}\right]$ assemblies, constituted by a $\left[\mathrm{Pd}_{3} \mathrm{~L}_{6}^{\mathrm{A}}\right]$ ring and a $\left[\mathrm{Pd}_{4} \mathrm{~L}_{8}^{\mathrm{A}}\right]$ tetrahedron as major components, and a $\left[\mathrm{Pd}_{6} \mathrm{~L}^{\mathrm{A}}{ }_{12}\right]$ octahedron as minor component. Introduction of backbone steric hindrance in ligand $\mathrm{L}^{\mathrm{B}}$ allows exclusive formation of the $\left[\mathrm{Pd}_{6} \mathrm{~L}^{\mathrm{B}}{ }_{12}\right]$ octahedron. Combining equimolar amounts of both ligands results in integrative self-sorting to give an unprecedented $\left[\mathrm{Pd}_{4} \mathrm{~L}_{4}^{\mathrm{A}} \mathrm{L}_{4}^{\mathrm{B}}\right]$ heteroleptic tetrahedron. Key to the non-statistical assembly outcome is exploiting the structural peculiarity of the $\left[\mathrm{Pd}_{4} \mathrm{~L}_{8}\right]$ tetrahedral topology, where the four lean ligands occupy two doubly bridged edges and the bulky ligands span the four remaining, singly bridged edges. Hence, the system finds a compromise between the entropic drive to form an assembly smaller than the octahedron and the enthalpic prohibition of pairing two bulky ligands on the same edge of the triangular ring. The emission of luminescent $\mathrm{L}^{\mathrm{A}}$ is maintained in both homoleptic $\left[\mathrm{Pd}_{3} \mathrm{~L}_{6}^{\mathrm{A}}\right]$ and heteroleptic $\left[\mathrm{Pd}_{4} \mathrm{~L}_{4}^{\mathrm{A}} \mathrm{L}_{4}^{\mathrm{B}}\right]$.

$C_{\text {to }}$ oordination-driven self-assembly provides a powerful tool to design and synthesize discrete nanostructured objects with accessible cavities. ${ }^{1,2}$ The resulting metallo-supramolecular assemblies are promising candidates for mimicking functional host systems found in nature, such as enzymes. The dynamic nature of many transition metal-ligand interactions, characterized by precise geometry and directionality, combined with a polytopic ligand structure, allow us to design and self-assemble a plethora of compounds with different shapes, sizes, and properties. Embedded functions, depending on either individual building blocks or their synergistic interaction, ${ }^{3-7}$ may involve host-guest interactions, ${ }^{8-10}$ photoswitching, ${ }^{11,12}$ chirality, ${ }^{13-15}$ chromophore effects, ${ }^{16-19}$ or catalysis, ${ }^{20-23}$ just to name a few.

Besides the formation of single components, dynamic systems consisting of several structures with different topologies may be the result of a self-assembly reaction. ${ }^{24-29}$ So far, most reported metallo-supramolecular compounds carry only one type of ligand, limiting the possibility to exploit applications arising from the implementation of multiple functionalities. To overcome this restriction, we propose to increase structural complexity via the non-statistical integration of a set of different ligands. A first step in this direction is represented by homoleptic assemblies where the same ligand occupies two or more non-identical positions. For example, Lützen reported a $\left[\mathrm{Pd}_{2} \mathrm{~L}_{4}\right] @\left[\mathrm{Pd}_{4} \mathrm{~L}_{8}\right]$ cage-in-ring assembly. ${ }^{30}$ Shionoya differentiated metal positions, thus desymmetrizing a porphyrin ligand. ${ }^{31}$ Our group investigated the controlled formation of $\left[\mathrm{Pd}_{2} \mathrm{~L}_{3} \mathrm{X}_{2}\right]$ bowls $(\mathrm{X}=$ solvent, halides) featuring two different ligand environments. ${ }^{32,33}$ Recently, structural complexity has been increased using non-symmetric ligands. ${ }^{34-37} \mathrm{~A}$ further approach relies on the structural diversity of $\left[\mathrm{Pd}_{4} \mathrm{~L}_{8}\right]$ assemblies with bis-pyridyl ligands, making it possible to form rings, ${ }^{38}$ interpenetrated double cages, ${ }^{39,40}$ or a tetrahedron-like arrangement, featuring four edges composed of a single ligand and two doubly bridged edges. $5,41-43$

Complexity further increases when chemically different ligands are placed in defined positions, yielding heteroleptic species. To overcome the formation of a statistical mixture, ${ }^{44}$ several strategies have been applied, e.g., exploiting hydrogenbonding, ${ }^{45}$ templating guests, ${ }^{46}$ shape complementarity, ${ }^{47-53}$ or covalent bridges between ligands. ${ }^{54}$ Herein, we report a system where a bis-monodentate, flat ligand $\mathrm{L}^{\mathrm{A}}$ self-assembles with $\mathrm{Pd}^{\mathrm{II}}$ to give a series of $\left[\mathrm{Pd}_{n} \mathrm{~L}_{2 n}\right](n=3,4,6)$ architectures in a solvent-dependent process. Introduction of steric congestion into its backbone gives the bulky ligand $\mathrm{L}^{\mathrm{B}}$, allowing us to exclusively form a large $\left[\mathrm{Pd}_{6} \mathrm{~L}_{12}\right]$ octahedron. A similar approach was reported by Severin and Hiraoka based on clathrochelate metallo-ligands. ${ }^{55,56}$ We now show that combining lean ligand $\mathrm{L}^{\mathrm{A}}$ and bulky derivative $\mathrm{L}^{\mathrm{B}}$ opens a new strategy to form unprecedented $\left[\mathrm{Pd}_{4} \mathrm{~L}_{4}^{\mathrm{A}} \mathrm{L}_{4}^{\mathrm{B}}\right]$ heteroleptic structures. Key to clean, integrative self-sorting is the presence of two non-equivalent edge types in the $\left[\mathrm{Pd}_{4} \mathrm{~L}_{8}\right]$ tetrahedron, combined with control over steric pressure in the ligand backbones.

Ligands $\mathrm{L}^{\mathrm{A}}$ and $\mathrm{L}^{\mathrm{B}}$ were synthesized by Suzuki crosscoupling starting from 2,7-dibromo-9-fluorenone and 2,7dibromo-9,9-dihexylfluorene, respectively, with 3-pyridineboronic acid pinacol ester (Supporting Information (SI)). Using 9-substituted fluorene-based backbones makes it possible to obtain non-linear bis-pyridyl ligands, bearing the $\mathrm{C}=\mathrm{O}$ or

Received: February 18, 2021

Published: April 26, 2021 


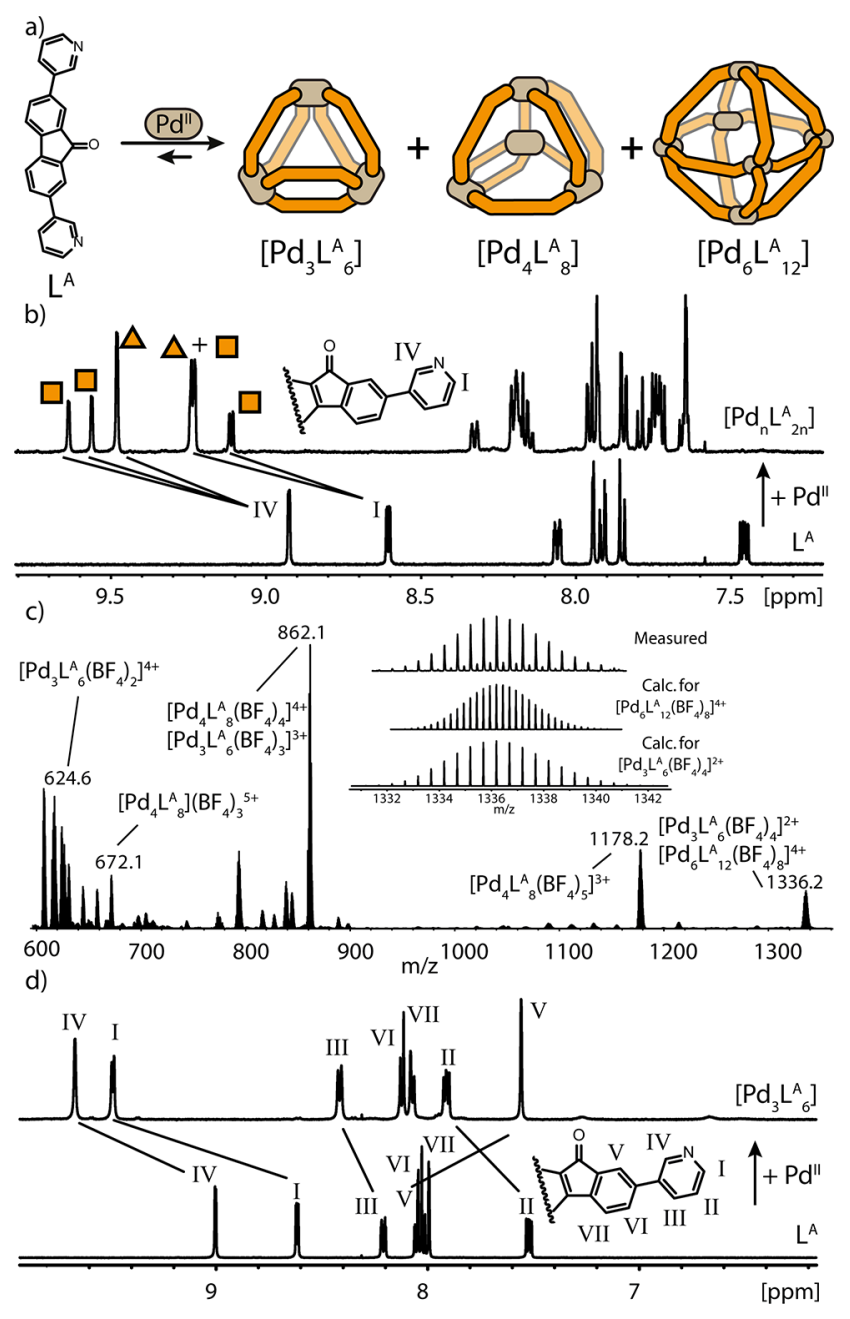

Figure 1. (a) Self-assembly of $\mathrm{Pd}^{\mathrm{II}}$ and $\mathrm{L}^{\mathrm{A}}$ forms a $\left[\mathrm{Pd}_{n} \mathrm{~L}_{2 n}\right]$ solventdependent library. (b) ${ }^{1} \mathrm{H}$ NMR $\left(\mathrm{CD}_{3} \mathrm{CN}, 500 \mathrm{MHz}\right)$ spectra of $\left[\mathrm{Pd}_{3} \mathrm{~L}_{6}^{\mathrm{A}}\right]$ (triangles)/ $\left[\mathrm{Pd}_{4} \mathrm{~L}_{8}^{\mathrm{A}}\right]$ (squares) and $\mathrm{L}^{\mathrm{A}}$. (c) ESI-MS spectrum of $\left[\mathrm{Pd}_{n} \mathrm{~L}_{2 n}\right]$ in $\mathrm{CH}_{3} \mathrm{CN}$; inset shows the isotopic patterns for $\left[\mathrm{Pd}_{3} \mathrm{~L}_{6}^{\mathrm{A}}\left(\mathrm{BF}_{4}\right)_{4}\right]^{2+}$ and $\left[\mathrm{Pd}_{6} \mathrm{~L}^{\mathrm{A}}{ }_{12}\left(\mathrm{BF}_{4}\right)_{8}\right]^{4+}$. (d) ${ }^{1} \mathrm{H}$ NMR (DMSO$\left.d_{6}, 500 \mathrm{MHz}\right)$ of $\left[\mathrm{Pd}_{3} \mathrm{~L}_{6}^{\mathrm{A}}\right]$ and $\mathrm{L}^{\mathrm{A}}$.

alkyl substituents pointing toward one side of the molecule. This generates two binding modes: convex $\left(\theta \approx 90^{\circ}\right)$ with nitrogen donors pointing away from the substituent(s), and concave $\left(\theta \approx 40^{\circ}\right)$ pointing in the same direction (Scheme S4). A similar backbone design was reported to lead to $\mathrm{Fe}$ based helicates and tetrahedra, ${ }^{57-60}$ as well as knots and Borromean rings. $^{61}$

At first, we studied the self-assembly of homoleptic species. Combination of ligand $\mathrm{L}^{\mathrm{A}}$ with $\mathrm{Pd}^{\mathrm{II}}$ in a $2: 1$ ratio led to a solvent-dependent dynamic library of compounds with different nuclearity (Figure $1 \mathrm{a}$ ). In $\mathrm{CD}_{3} \mathrm{CN}$, two major components are formed, a $\left[\mathrm{Pd}_{3} \mathrm{~L}_{6}^{\mathrm{A}}\right]$ triangular ring and a $\left[\mathrm{Pd}_{4} \mathrm{~L}_{8}^{\mathrm{A}}\right]$ tetrahedron. After coordination to $\mathrm{Pd}^{\mathrm{II}},{ }^{1} \mathrm{H}$ NMR signals are downfield shifted and split into three sets, as clearly observed for proton $\mathrm{H}_{\mathrm{IV}}$, with a 1:1:2 ratio (Figure $1 \mathrm{~b}$ ). NOESY-NMR allows us to identify two independent sets of signals (SI), while DOSY-NMR shows the presence of two species in solution, with hydrodynamic radii of 11.04 and $12.19 \AA$, respectively (SI). This is consistent with the formation of a $\left[\mathrm{Pd}_{3} \mathrm{~L}_{6}^{\mathrm{A}}\right]$ ring and $\mathrm{a}\left[\mathrm{Pd}_{4} \mathrm{~L}_{8}^{\mathrm{A}}\right]$ tetrahedron, the latter generating two set of ${ }^{1} \mathrm{H}$ NMR signals due to two non-equivalent ligand positions. Support comes from high-resolution ESI-MS analysis, showing a series of signals for $\left[\mathrm{Pd}_{3} \mathrm{~L}_{6}^{\mathrm{A}}\left(\mathrm{BF}_{4}\right)_{n}\right]^{m+}(n=2-4 ; m=4-2)$ and $\left[\mathrm{Pd}_{4} \mathrm{~L}_{8}^{\mathrm{A}}\left(\mathrm{BF}_{4}\right)_{n}\right]^{m+}(n=4,5 ; m=4,3)$ (Figure $1 \mathrm{c}$ ). Interestingly, the signal at $m / z=1336.2$ reveals the presence of $\left[\mathrm{Pd}_{3} \mathrm{~L}_{6}^{\mathrm{A}}\left(\mathrm{BF}_{4}\right)_{4}\right]^{2+}$ as major and higher-nuclear $\left[\mathrm{Pd}_{6} \mathrm{~L}_{12}^{\mathrm{A}}\left(\mathrm{BF}_{4}\right)_{8}\right]^{4+}$ as minor components (Figure 1c, inset). Self-assembly in DMSO- $d_{6}$ results in only $\left[\mathrm{Pd}_{3} \mathrm{~L}_{6}^{\mathrm{A}}\right]$ ring formation, as confirmed by ${ }^{1} \mathrm{H}$ NMR (Figure 1d), DOSY$\operatorname{NMR}\left(r_{\mathrm{H}}=13.20 \AA\right)$, and ESI-MS analysis (SI). The structures for all three $\left[\mathrm{Pd}_{n} \mathrm{~L}_{2 n}\right]$ components have been determined by single-crystal X-ray diffraction (SCXRD) analysis (Figure 2). Needle-shaped crystals of the trimetallic
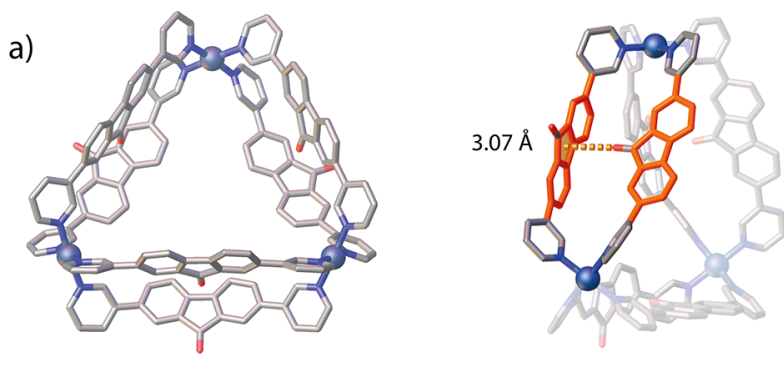

$\left[\mathrm{Pd}_{3} \mathrm{~L}_{6}^{\mathrm{A}}\right]$

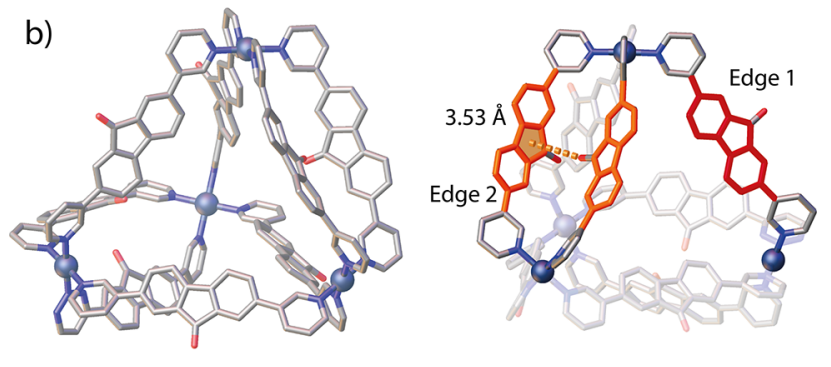

$\left[\mathrm{Pd}_{4} \mathrm{~L}_{8}^{\mathrm{A}}\right]$
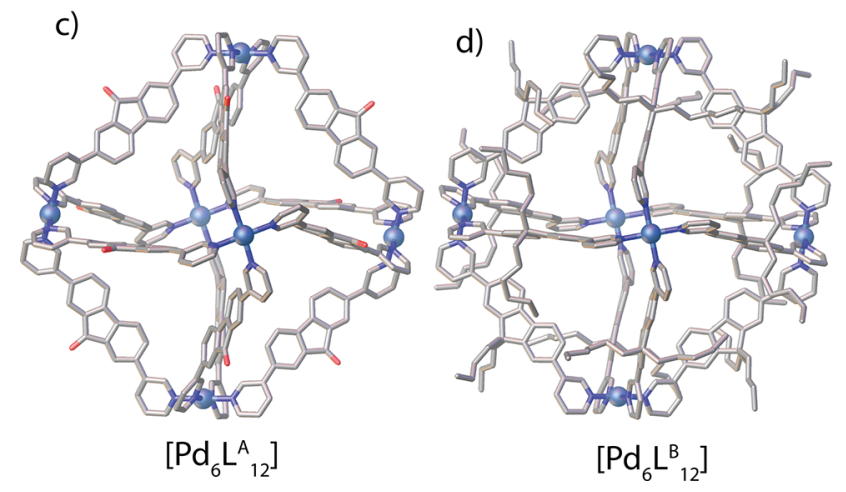

Figure 2. SCXRD structures of (a) $\left[\mathrm{Pd}_{3} \mathrm{~L}_{6}^{\mathrm{A}}\right]$ ring (left), highlighting the $\mathrm{C}=\mathrm{O}-\pi$ interaction (right); (b) $\left[\mathrm{Pd}_{4} \mathrm{~L}^{\mathrm{A}}{ }_{8}\right]$ tetrahedron (left), highlighting edge 1 (red), edge 2 (orange), and the $\mathrm{C}=\mathrm{O}-\pi$ interaction (right); (c) $\left[\mathrm{Pd}_{6} \mathrm{~L}^{\mathrm{A}}{ }_{12}\right]$ octahedron (one enantiomer shown); and (d) $\left[\mathrm{Pd}_{6} \mathrm{~L}^{\mathrm{B}}{ }_{12}\right]$ octahedron. Counterions, solvent molecules, hydrogen atoms, and disorder are omitted for clarity. Color code: Pd, metallic blue; N, blue; O, red; C, gray.

$\left[\mathrm{Pd}_{3} \mathrm{~L}_{6}^{\mathrm{A}}\right]$ were obtained by vapor diffusion of toluene into a DMSO solution. The compound has the expected triangular geometry, where $\mathrm{Pd}^{\mathrm{II}}$ metal centers occupy the vertices while pairs of ligands sit on the edges (Figure 2a). The carbonyl backbone substituent adopts two positions, one pointing outside the ring cavity while the other points toward the $\pi$ surface of the neighboring ligand. The distance between the fluorenone oxygen and the 5-membered ring centroid of $\mathrm{L}^{\mathrm{A}}$ is 
$3.07 \AA$, suggesting the incompatibility of a bulkier backbone substituent with this structure. Diffusion of ethyl acetate into a DMF solution yielded single crystals of $\left[\mathrm{Pd}_{4} \mathrm{~L}_{8}^{\mathrm{A}}\right]$, yielding a tetrahedral structure with $\mathrm{Pd}^{\mathrm{II}}$ centers on the vertices and ligands bridging the edges (Figure 2b). In this case, $\mathrm{L}^{\mathrm{A}}$ occupies two non-equivalent positions: four edges ("edge 1") are composed of one ligand, while the two remaining edges ("edge 2") accommodate a pair of ligands. In edge 1, the carbonyl substituent points outside the tetrahedral cavity, with $\mathrm{L}^{\mathrm{A}}$ adopting a convex binding mode $\left(\theta \approx 80^{\circ}\right)$. In edge 2 , the carbonyl group of one $\mathrm{L}^{\mathrm{A}}$ points toward the $\pi$-surface of its neighbor $\left(\mathrm{C}=\mathrm{O}-\pi-\mathrm{C}_{5}\right.$ centroid $=3.53 \AA$ ), while the other carbonyl group points inside the cavity, featuring a concave binding mode $\left(\theta \approx 40^{\circ}\right)$. Finally, diffusion of 1,4-dioxane into the $\left[\mathrm{Pd}_{n} \mathrm{~L}_{2 n}^{\mathrm{A}}\right](n=3,4,6) \mathrm{CH}_{3} \mathrm{CN}$ solution resulted in single crystals of $\left[\mathrm{Pd}_{6} \mathrm{~L}_{12}^{\mathrm{A}}\right]$, suitable for synchrotron diffraction analysis. The compound crystallizes in the $R \overline{3}$ space group as a pair of enantiomeric $\left[\mathrm{Pd}_{6} \mathrm{~L}^{\mathrm{A}}{ }_{12}\right]$ octahedra (Figure $2 \mathrm{c}$ ). $\mathrm{Pd}^{\mathrm{II}}$ cations occupy the vertices, while the edges feature one ligand $\mathrm{L}^{\mathrm{A}}$ each, with all carbonyl groups pointing outside the cavity. Comparing the three $\left[\mathrm{Pd}_{n} \mathrm{~L}_{2 n}^{\mathrm{A}}\right]$ structures suggests that only the octahedron, the sole structure without $\mathrm{C}=\mathrm{O}-\pi$ interactions, should be able to accommodate sterically demanding ligands on all edges.

To explore this possibility, $\mathrm{L}^{\mathrm{B}}$ was synthesized by replacing the 9-fluorenone with a 9,9-dihexylfluorene backbone. Selfassembly of $\mathrm{L}^{\mathrm{B}}$ with $\mathrm{Pd}^{\mathrm{II}}$ cations in a 2:1 stoichiometry led to the formation of a single species, identified as a $\left[\mathrm{Pd}_{6} \mathrm{~L}_{12}^{\mathrm{B}}\right]$ octahedron (Figure $3 \mathrm{a}$ ). Upon complexation of $\mathrm{Pd}^{\mathrm{II}}$, the ${ }^{1} \mathrm{H}$

$$
\text { a) }
$$
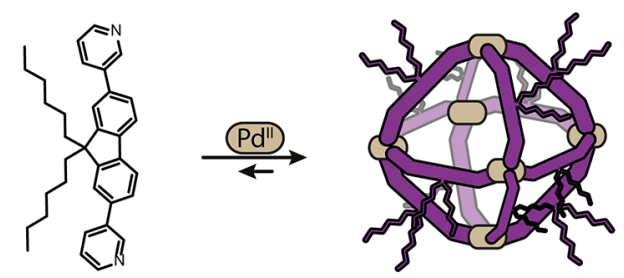

b)

$\mathrm{L}^{\mathrm{B}}$
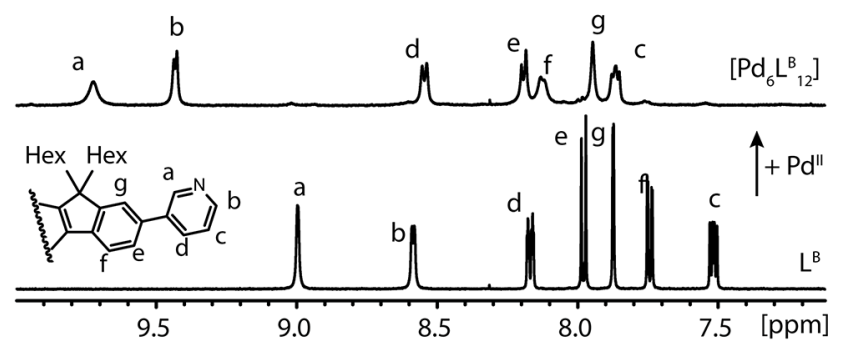

c)

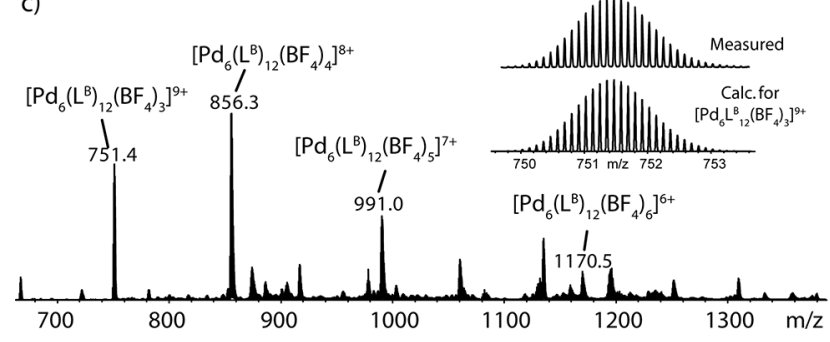

Figure 3. (a) Self-assembly of $\mathrm{Pd}^{\mathrm{II}}$ and $\mathrm{L}^{\mathrm{B}}$ to form $\left[\mathrm{Pd}_{6} \mathrm{~L}^{\mathrm{B}}{ }_{12}\right]$. (b) ${ }^{1} \mathrm{H}$ NMR (DMSO- $d_{6}, 500 \mathrm{MHz}$ ) spectra of $\left[\mathrm{Pd}_{6} \mathrm{~L}^{\mathrm{B}}{ }_{12}\right]$ and $\mathrm{L}^{\mathrm{B}}$. (c) ESIMS spectrum of $\left[\mathrm{Pd}_{6} \mathrm{~L}^{\mathrm{B}}{ }_{12}\right]$ with isotopic pattern of $\left[\mathrm{Pd}_{6} \mathrm{~L}^{\mathrm{B}}{ }_{12}\left(\mathrm{BF}_{4}\right)_{3}\right]^{9+}$ shown in the inset.
NMR signals of $\mathrm{L}^{\mathrm{B}}$ are downfield shifted and slightly broadened (Figure 3b). DOSY analysis confirmed a single species in $\mathrm{CD}_{3} \mathrm{CN}\left(r_{\mathrm{H}}=15.22 \AA\right)$ and DMSO- $d_{6}\left(r_{\mathrm{H}}=18.66\right.$ $\AA$, SI), while pointing to differences in the solvent shell dynamics around the heavily alkyl-decorated $\left[\mathrm{Pd}_{6} \mathrm{~L}^{\mathrm{B}}{ }_{12}\right]$ species. The high nuclearity was confirmed by HR-ESI-MS, where a series of peaks for $\left[\mathrm{Pd}_{6} \mathrm{~L}^{\mathrm{B}}{ }_{12}\left(\mathrm{BF}_{4}\right)_{n}\right]^{m+}(n=3-6 ; m=9-6)$ were identified (Figure $3 \mathrm{c}$ ). Moreover, single crystals were obtained from vapor diffusion of toluene into a DMSO solution. The compound crystallizes as an octahedron with a structure analogous to that of $\left[\mathrm{Pd}_{6} \mathrm{~L}^{\mathrm{A}}{ }_{12}\right] . \mathrm{L}^{\mathrm{B}}$ sits on the edges and coordinates in the convex mode, and all hexyl chains point outside the cavity (Figure $2 \mathrm{~d}$ ). From these results we inferred that the steric bulk in the backbones of $\mathrm{L}^{\mathrm{B}}$ prevents two ligands from being direct neighbors on the same edge, thus averting formation of entropically favored homoleptic species $\left[\mathrm{Pd}_{3} \mathrm{~L}_{6}\right]$ or $\left[\mathrm{Pd}_{4} \mathrm{~L}_{8}\right]$.

Looking at the $\left[\mathrm{Pd}_{4} \mathrm{~L}_{8}^{\mathrm{A}}\right]$ tetrahedral structure (Figure $2 \mathrm{~b}$ ) reveals that while edge 2 must fit two ligands, edge 1 can accommodate a single ligand with a bulkier backbone, adopting a convex binding mode with substituents pointing outside the cavity. Based on this assumption, we postulated the formation of an unprecedented heteroleptic $\left[\mathrm{Pd}_{4} \mathrm{~L}_{4}^{\mathrm{A}} \mathrm{L}_{4}^{\mathrm{B}}\right]$ tetrahedron, with four $L^{A}$ sitting on edges 1 , while ligands $L^{B}$ occupy edges 2. Hence, $\mathrm{Pd}^{\mathrm{II}}, \mathrm{L}^{\mathrm{A}}$, and $\mathrm{L}^{\mathrm{B}}$ were mixed in a $1: 1: 1$ ratio in DMSO- $d_{6}$ at $70{ }^{\circ} \mathrm{C}$ for $1 \mathrm{~h}$, indeed resulting in the exclusive formation of a $\left[\mathrm{Pd}_{4} \mathrm{~L}_{4}^{\mathrm{A}} \mathrm{L}^{\mathrm{B}}{ }_{4}\right]$ heteroleptic tetrahedron (Figure 4b). ${ }^{1} \mathrm{H}$ NMR signals show downfield shifting, without signs of any homoleptic assemblies (Figure $4 \mathrm{c}$ ). The presence of both $\mathrm{L}^{\mathrm{A}}$ and $\mathrm{L}^{\mathrm{B}}$ within the same structure is supported by NOESYNMR, showing a number of cross-signals, e.g., between $\mathrm{H}_{\mathrm{b}}$ and $\mathrm{H}_{\mathrm{I}}(\mathrm{SI})$. DOSY-NMR clearly shows a single species $\left(r_{\mathrm{H}}=\right.$ $15.11 \AA)$, bigger than $\left[\mathrm{Pd}_{3} \mathrm{~L}^{\mathrm{A}}{ }_{6}\right]$, but smaller compared to $\left[\mathrm{Pd}_{6} \mathrm{~L}^{\mathrm{B}}{ }_{12}\right]$ in the same solvent (Figure S36). Furthermore, in the ESI-MS spectrum, a series of peaks for $\left[\mathrm{Pd}_{4} \mathrm{~L}_{4}^{\mathrm{A}} \mathrm{L}_{4}^{\mathrm{B}}\left(\mathrm{BF}_{4}\right)_{n}\right]^{m+}(n=1-5 ; m=7-3)$ were identified (Figure $4 \mathrm{~d}$ ). Due to the dynamic nature of the metallosupramolecular system, the same result was obtained in the fashion of a "cage-to-cage transformation" when two equimolar solutions of $\left[\mathrm{Pd}_{3} \mathrm{~L}_{6}^{\mathrm{A}}\right]$ and $\left[\mathrm{Pd}_{6} \mathrm{~L}_{12}^{\mathrm{B}}\right]$ were mixed (Figure $\mathrm{S} 33$ ). Despite a longer reaction time (Figure S34) than starting from free ligands plus $\mathrm{Pd}^{\mathrm{II}}$, in agreement with our previous findings, ${ }^{49}$ this proves that $\left[\mathrm{Pd}_{4} \mathrm{~L}_{4}^{\mathrm{A}} \mathrm{L}^{\mathrm{B}}{ }_{4}\right]$ is a thermodynamic product.

Structural analysis of single crystals, from benzene vapor diffusion into DMSO, ultimately proved the formation of a $\left[\mathrm{Pd}_{4} \mathrm{~L}_{4}^{\mathrm{A}} \mathrm{L}^{\mathrm{B}}{ }_{4}\right]$ heteroleptic tetrahedron (Figure $4 \mathrm{a}$ ). To the best of our knowledge, this is the first example of such a $\left[\mathrm{M}_{4} \mathrm{~L}_{4}^{\mathrm{A}} \mathrm{L}_{4}^{\mathrm{B}}\right]$ heteroleptic assembly topology. As postulated, four ligands $\mathrm{L}^{\mathrm{A}}$ are accommodated on edges 2 , with the $\mathrm{C}=\mathrm{O}$ group either pointing inside the cavity or facing the $\pi$-surface of neighboring $\mathrm{L}^{\mathrm{A}}\left(\mathrm{C}=\mathrm{O}-\pi-\mathrm{C}_{5}\right.$ centroid $=3.38 \AA$, Figure $\left.4 \mathrm{a}\right)$. In addition, four ligands $L^{B}$ are sitting on edges 1 , adopting a convex binding mode with hexyl chains pointing outside the cavity (Figure 4a, purple backbone).

Next, we investigated guest binding of one aliphatic and two aromatic bis-sulfonates (Scheme S5) with $\left[\mathrm{Pd}_{3} \mathrm{~L}_{6}^{\mathrm{A}}{ }_{6}\right],\left[\mathrm{Pd}_{6} \mathrm{~L}^{\mathrm{B}}{ }_{12}\right]$ and $\left[\mathrm{Pd}_{4} \mathrm{~L}_{4}^{\mathrm{A}} \mathrm{L}_{4}^{\mathrm{B}}\right]$ in DMSO- $d_{6}$. In all cases, ${ }^{1} \mathrm{H}$ NMR titrations show interaction of the guests with the cage's inner cavity, indicated by a shift of inward-pointing protons (SI). Signal broadening and onset of precipitation prevented us from determining association constants. ESI-MS analysis, however, suggests that the maximal number of hosted guests is 


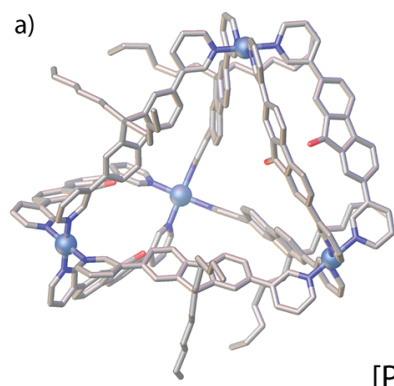

b)
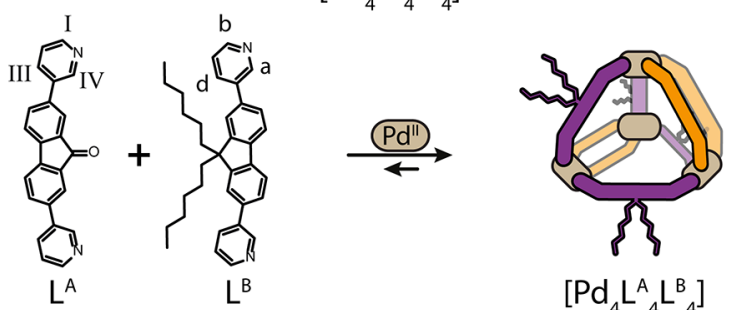

$\left[\mathrm{Pd}_{4} \mathrm{~L}_{4}^{\mathrm{A}} \mathrm{L}^{\mathrm{B}}{ }_{4}\right]$

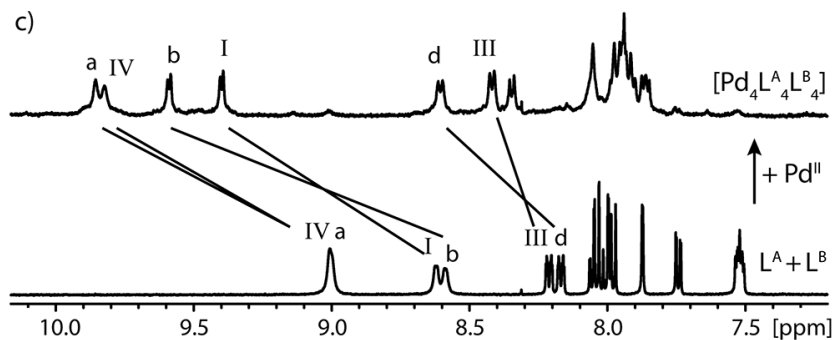

d)

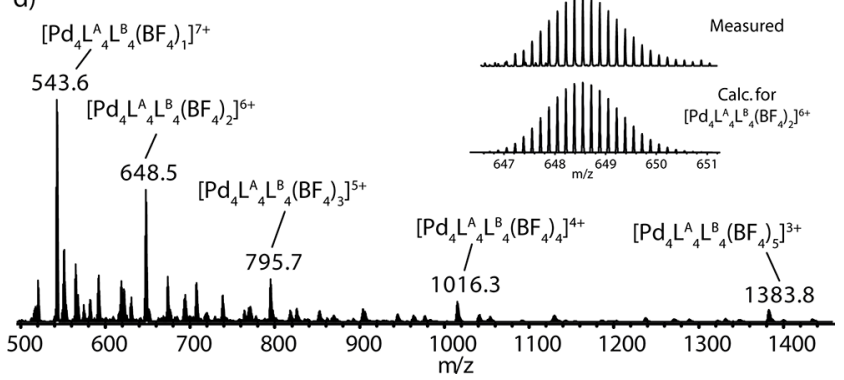

Figure 4. (a) SCXRD structure of $\left[\mathrm{Pd}_{4} \mathrm{~L}_{4}^{\mathrm{A}} \mathrm{L}^{\mathrm{B}}{ }_{4}\right]$ (left), highlighting $\mathrm{L}^{\mathrm{A}}$ (orange) and $\mathrm{L}^{\mathrm{B}}$ (purple) positions and the $\mathrm{C}=\mathrm{O}-\pi$ interaction (right). Counterions, solvent molecules, hydrogen atoms, and disorder are omitted for clarity. Color code: $\mathrm{Pd}$, metallic blue; $\mathrm{N}$, blue; O, red; C, gray. (b) Self-assembly of $\mathrm{Pd}^{\mathrm{II}}$ with $\mathrm{L}^{\mathrm{A}}$ and $\mathrm{L}^{\mathrm{B}}$ forms $\left[\mathrm{Pd}_{4} \mathrm{~L}_{4}^{\mathrm{A}} \mathrm{L}_{4}^{\mathrm{B}}\right]$. (c) ${ }^{1} \mathrm{H}$ NMR (DMSO- $d_{6}, 500 \mathrm{MHz}$ ) spectra of $\left[\mathrm{Pd}_{4} \mathrm{~L}_{4}{ }_{4} \mathrm{~L}^{\mathrm{B}}{ }_{4}\right]$ and a $1: 1$ mixture of $\mathrm{L}^{\mathrm{A}}$ and $\mathrm{L}^{\mathrm{B}}$. (d) ESI-MS spectrum of $\left[\mathrm{Pd}_{4} \mathrm{~L}_{4}^{\mathrm{A}} \mathrm{L}_{4}^{\mathrm{B}}\right]$, with isotopic pattern of $\left[\mathrm{Pd}_{4} \mathrm{~L}_{4}^{\mathrm{A}} \mathrm{L}_{4}^{\mathrm{B}}\left(\mathrm{BF}_{4}\right)_{3}\right]^{6+}$ shown in the inset.

controlled by the assembly size. While for $\left[\mathrm{Pd}_{3} \mathrm{~L}_{6}^{\mathrm{A}}\right]$ we only observed interaction with one guest, for tetrahedra $\left[\mathrm{Pd}_{4} \mathrm{~L}_{8}^{\mathrm{A}}\right]$ and $\left[\mathrm{Pd}_{4} \mathrm{~L}_{4}^{\mathrm{A}} \mathrm{L}^{\mathrm{B}}{ }_{4}\right]$ binding of two guests was detected, and large octahedron $\left[\mathrm{Pd}_{6} \mathrm{~L}^{\mathrm{B}}{ }_{12}\right]$ was even found to bind up to three guest molecules (SI).

Finally, we investigated the photophysical properties of the systems (Figure 5). In DMSO, $\mathrm{L}^{\mathrm{A}}$ shows an emission band centered at $555 \mathrm{~nm}$ that is blue-shifted to $532 \mathrm{~nm}$ upon $\mathrm{Pd}^{\mathrm{II}}$ complexation in either homoleptic $\left[\mathrm{Pd}_{3} \mathrm{~L}_{6}^{\mathrm{A}}\right]$ or heteroleptic $\left[\mathrm{Pd}_{4} \mathrm{~L}_{4}^{\mathrm{A}} \mathrm{L}_{4}^{\mathrm{B}}\right]$. While this indicates that the emissive properties of ligand $\mathrm{L}^{\mathrm{A}}$ are retained in the heteroleptic tetrahedron, our platform allows to introduce additional functionality through modification of $\mathrm{L}^{\mathrm{B}}$. It is worth noting that in Pd-mediated assemblies luminescence quenching is frequently observed, ${ }^{15,39}$

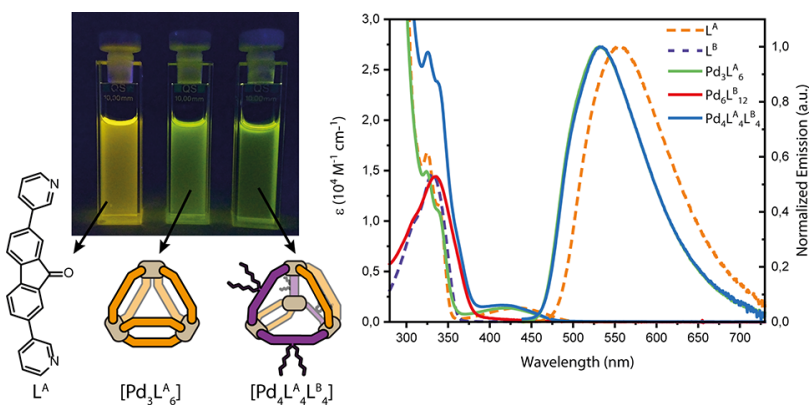

Figure 5. Absorption spectra of ligands and cages $\left(5.0 \times 10^{-4} \mathrm{M}\right.$ referred to ligand concentration; DMSO) and normalized emission spectra of $\mathrm{L}^{\mathrm{A}},\left[\mathrm{Pd}_{3} \mathrm{~L}_{6}^{\mathrm{A}}\right]$, and $\left[\mathrm{Pd}_{4} \mathrm{~L}_{4}^{\mathrm{A}} \mathrm{L}_{4}^{\mathrm{B}}\right]\left(1.4 \times 10^{-4} \mathrm{M} ; \lambda_{\text {ex }}=430\right.$ $\mathrm{nm})$.

and only few examples of emissive cages have been reported so far. ${ }^{18,62-65}$

To conclude, we report a new strategy for the non-statistical, integrative self-assembly of a previously unreported $\left[\mathrm{M}_{4} \mathrm{~L}_{4}{ }_{4} \mathrm{~L}_{4}^{\mathrm{B}}\right]$ heteroleptic cage topology. Key factors are the use of bis-monodentate ligands, able to adopt a concave or convex binding mode, the precise introduction of backbone steric hindrance, and a balance between the entropic tendency to form small assemblies and the enthalpic disadvantage to pair bulky substituents on a single edge. The preservation of ligand emission properties in the Pd-mediated assemblies opens potential toward application as multifunctional devices and materials in fields such chiroptical sensing, donor-acceptor systems, and photoredox catalysis.

\section{ASSOCIATED CONTENT}

\section{SI Supporting Information}

The Supporting Information is available free of charge at https://pubs.acs.org/doi/10.1021/jacs.1c01931.

Synthetic procedures, NMR, MS, SCXRD, and spectroscopic data, including Schemes S1-S5, Figures S1-S48, Tables S1-S3 (PDF)

\section{Accession Codes}

CCDC 2061340, 2061344, 2061345, 2061347, 2061350, and 2061351 contain the supplementary crystallographic data for this paper. These data can be obtained free of charge via www.ccdc.cam.ac.uk/data_request/cif, or by emailing data request@ccdc.cam.ac.uk, or by contacting The Cambridge Crystallographic Data Centre, 12 Union Road, Cambridge CB2 1EZ, UK; fax: +44 1223336033

\section{AUTHOR INFORMATION}

\section{Corresponding Author}

Guido H. Clever - Department of Chemistry and Chemical Biology, TU Dortmund University, 44227 Dortmund, Germany; 이이.org/0000-0001-8458-3060; Email: guido.clever@tu-dortmund.de

\section{Authors}

Jacopo Tessarolo - Department of Chemistry and Chemical Biology, TU Dortmund University, 44227 Dortmund, Germany

Haeri Lee - Department of Chemistry, Hannam University, Daejeon 34054, Republic of Korea

Eri Sakuda - Department of Chemistry and Chemical Biology, TU Dortmund University, 44227 Dortmund, Germany; 
Division of Chemistry and Materials Science, Graduate School of Engineering, Nagasaki University, Nagasaki 8528521, Japan; 이이.org/0000-0001-9882-7628

Keisuke Umakoshi - Division of Chemistry and Materials Science, Graduate School of Engineering, Nagasaki University, Nagasaki 852-8521, Japan; 이이.org/00000002-2027-6333

Complete contact information is available at: https://pubs.acs.org/10.1021/jacs.1c01931

\section{Notes}

The authors declare no competing financial interest.

\section{ACKNOWLEDGMENTS}

This work was supported by the European Research Council (ERC Consolidator grant 683083, RAMSES). We acknowledge DESY (Hamburg, Germany), a member of the Helmholtz Association HGF, for access to PETRA III and thank Dr. Anja Burkhardt for assistance in using synchrotron beamline P11 (I20180990). E.S. thanks the JSPS program for Advancing Strategic International Networks to Accelerate the Circulation of Talented Researchers and JSPS for KAKENHI Grant No. JP20H05834. The authors thank Dr. Julian J. Holstein for integrating the synchrotron data, Dr. Ananya Baksi and Laura Schneider for measuring mass spectra, and Simon Kotnig for resynthesizing $\mathrm{L}^{\mathrm{A}}$. H.L. was supported by a National Research Foundation of Korea grant funded by the Korean Government (NRF-2018R1A6A3A03012675).

\section{REFERENCES}

(1) Chakrabarty, R.; Mukherjee, P. S.; Stang, P. J. Supramolecular Coordination: Self-Assembly of Finite Two- and Three-Dimensional Ensembles. Chem. Rev. 2011, 111, 6810-6918.

(2) Saha, S.; Regeni, I.; Clever, G. H. Structure Relationships between Bis-Monodentate Ligands and Coordination Driven SelfAssemblies. Coord. Chem. Rev. 2018, 374, 1-14.

(3) Sun, Q.-F.; Iwasa, J.; Ogawa, D.; Ishido, Y.; Sato, S.; Ozeki, T.; Sei, Y.; Yamaguchi, K.; Fujita, M. Self-Assembled $\mathrm{M}_{24} \mathrm{~L}_{48}$ Polyhedra and Their Sharp Structural Switch upon Subtle Ligand Variation. Science 2010, 328, 1144-1147.

(4) Fujita, D.; Ueda, Y.; Sato, S.; Yokoyama, H.; Mizuno, N.; Kumasaka, T.; Fujita, M. Self-Assembly of $\mathrm{M}_{30} \mathrm{~L}_{60}$ Icosidodecahedron. Chem. 2016, 1, 91-101.

(5) Jansze, S. M.; Cecot, G.; Wise, M. D.; Zhurov, K. O.; Ronson, T. K.; Castilla, A. M.; Finelli, A.; Pattison, P.; Solari, E.; Scopelliti, R.; Zelinskii, G. E.; Vologzhanina, A. V.; Voloshin, Y. Z.; Nitschke, J. R.; Severin, K. Ligand Aspect Ratio as a Decisive Factor for the SelfAssembly of Coordination Cages. J. Am. Chem. Soc. 2016, 138, 20462054.

(6) Liu, C.-L.; Bobylev, E. O.; Fu, Y.; Poole, D. A.; Robeyns, K.; Fustin, C.-A.; Garcia, Y.; Reek, J. N. H.; Singleton, M. Balancing Ligand Flexibility Versus Rigidity for the Step-Wise Self-Assembly of $\mathrm{M}_{12} \mathrm{~L}_{24}$ Via $\mathrm{M}_{6} \mathrm{~L}_{12}$ Metal-Organic Cages. Chem. - Eur. J. 2020, 26, 11960-11965.

(7) Seidel, S. R.; Stang, P. J. High-Symmetry Coordination Cages via Self-Assembly. Acc. Chem. Res. 2002, 35, 972-983.

(8) Mal, P.; Breiner, B.; Rissanen, K.; Nitschke, J. R. White Phosphorus Is Air-Stable Within a Self-Assembled Tetrahedral Capsule. Science 2009, 324, 1697-1699.

(9) Rizzuto, F. J.; von Krbek, L. K. S.; Nitschke, J. R. Strategies for Binding Multiple Guests in Metal-Organic Cages. Nat. Rev. Chem. 2019, 3, 204-222.

(10) Löffler, S.; Wuttke, A.; Zhang, B.; Holstein, J. J.; Mata, R. A.; Clever, G. H. Influence of Size, Shape, Heteroatom Content and
Dispersive Contributions on Guest Binding in a Coordination Cage. Chem. Commun. 2017, 53, 11933-11936.

(11) Stuckhardt, C.; Roke, D.; Danowski, W.; Otten, E.; Wezenberg, S. J.; Feringa, B. L. A Chiral Self-Sorting Photoresponsive Coordination Cage Based on Overcrowded Alkenes. Beilstein J. Org. Chem. 2019, 15, 2767-2773.

(12) Li, R.-J.; Holstein, J. J.; Hiller, W. G.; Andréasson, J.; Clever, G. H. Mechanistic Interplay between Light Switching and Guest Binding in Photochromic $\left[\mathrm{Pd}_{2}\right.$ Dithienylethene $\left.{ }_{4}\right]$ Coordination Cages. J. Am. Chem. Soc. 2019, 141, 2097-2103.

(13) Zhang, D.; Ronson, T. K.; Greenfield, J. L.; Brotin, T.; Berthault, P.; Léonce, E.; Zhu, J.-L.; Xu, L.; Nitschke, J. R. Enantiopure $\left[\mathrm{Cs}^{+} / \mathrm{XeCCryptophane}\right] \subset \mathrm{Fe}^{\mathrm{II}}{ }_{4} \mathrm{~L}_{4}$ Hierarchical Superstructures. J. Am. Chem. Soc. 2019, 141, 8339-8345.

(14) Rizzuto, F. J.; Pröhm, P.; Plajer, A. J.; Greenfield, J. L.; Nitschke, J. R. Hydrogen-Bond-Assisted Symmetry Breaking in a Network of Chiral Metal-Organic Assemblies. J. Am. Chem. Soc. 2019, 141, 1707-1715.

(15) Schulte, T. R.; Holstein, J. J.; Clever, G. H. Chiral SelfDiscrimination and Guest Recognition in Helicene-Based Coordination Cages. Angew. Chem., Int. Ed. 2019, 58, 5562-5566.

(16) Yan, X.; Wei, P.; Liu, Y.; Wang, M.; Chen, C.; Zhao, J.; Li, G.; Saha, M. L.; Zhou, Z.; An, Z.; Li, X.; Stang, P. J. Endo- and ExoFunctionalized Tetraphenylethylene $\mathrm{M}_{12} \mathrm{~L}_{24}$ Nanospheres: Fluorescence Emission Inside a Confined Space. J. Am. Chem. Soc. 2019, 141, 9673-9679.

(17) Regeni, I.; Chen, B.; Frank, M.; Baksi, A.; Holstein, J. J.; Clever, G. H. Coal-Tar Dye-based Coordination Cages and Helicates. Angew. Chem., Int. Ed. 2021, 60, 5673-5678.

(18) Martir, D. R.; Escudero, D.; Jacquemin, D.; Cordes, D. B.; Slawin, A. M. Z.; Fruchtl, H. A.; Warriner, S. L.; Colman, E. Z. Homochiral Emissive $\Lambda_{8-}$ and $\Delta_{8-}\left[\mathrm{Ir}_{8} \mathrm{Pd}_{4}\right]^{16+}$ Supramolecular Cages. Chem. - Eur. J. 2017, 23, 14358-14366.

(19) Sun, Y.; Yao, Y.; Wang, H.; Fu, W.; Chen, C.; Saha, M. L.; Zhang, M.; Datta, S.; Zhou, Z.; Yu, H.; Li, X.; Stang, P. J. SelfAssembly of Metallacages into Multidimensional Suprastructures with Tunable Emissions. J. Am. Chem. Soc. 2018, 140, 12819-12828.

(20) Cullen, W.; Takezawa, H.; Fujita, M. Demethylenation of Cyclopropanes via Photoinduced Guest-to-Host Electron Transfer in an $\mathrm{M}_{6} \mathrm{~L}_{4}$ Cage. Angew. Chem., Int. Ed. 2019, 58, 9171-9173.

(21) Yoshizawa, M.; Klosterman, J. K.; Fujita, M. Functional Molecular Flasks: New Properties and Reactions within Discrete, SelfAssembled Hosts. Angew. Chem., Int. Ed. 2009, 48, 3418-3438.

(22) Murase, T.; Horiuchi, S.; Fujita, M. Naphthalene Diels-Alder in a Self-Assembled Molecular Flask. J. Am. Chem. Soc. 2010, 132, $2866-2867$.

(23) Hong, C. M.; Bergman, R. G.; Raymond, K. N.; Toste, F. D. Self-Assembled Tetrahedral Hosts as Supramolecular Catalysts. Acc. Chem. Res. 2018, 51, 2447-2455.

(24) Zhang, T.; Zhou, L.-P.; Guo, X.-Q.; Cai, L.-X.; Sun, Q.-F. Adaptive Self-Assembly and Induced-Fit Transformations of AnionBinding Metal-Organic Macrocycles. Nat. Commun. 2017, 8, 1589815906 .

(25) Riddell, I. A.; Smulders, M. M. J.; Clegg, J. K.; Hristova, Y. R.; Breiner, B.; Thoburn, J. D.; Nitschke, J. R. Anion-Induced Reconstitution of a Self-Assembling System to Express a ChlorideBinding $\mathrm{Co}_{10} \mathrm{~L}_{15}$ Pentagonal Prism. Nat. Chem. 2012, 4, 751-756.

(26) Riddell, I. A.; Hristova, Y. R.; Clegg, J. K.; Wood, C. S.; Breiner, B.; Nitschke, J. R. Five Discrete Multinuclear Metal-Organic Assemblies from One Ligand: Deciphering the Effects of Different Templates. J. Am. Chem. Soc. 2013, 135, 2723-2733.

(27) Hasenknopf, B.; Lehn, J.-M.; Boumediene, N.; Dupont-Gervais, A.; Van Dorsselaer, A.; Kneisel, B.; Fenske, D. Self-Assembly of Tetraand Hexanuclear Circular Helicates. J. Am. Chem. Soc. 1997, 119, 10956-10962.

(28) Hasenknopf, B.; Lehn, J.; Kneisel, B. O.; Baum, G.; Fenske, D. Self-Assembly of a Circular Double Helicate. Angew. Chem., Int. Ed. Engl. 1996, 35, 1838-1840. 
(29) Roy, B.; Saha, R.; Ghosh, A. K.; Patil, Y.; Mukherjee, P. S. Versatility of Two Diimidazole Building Blocks in CoordinationDriven Self-Assembly. Inorg. Chem. 2017, 56, 3579-3588.

(30) Käseborn, M.; Holstein, J. J.; Clever, G. H.; Lützen, A. A Rotaxane-like Cage-in-Ring Structural Motif for a Metallosupramolecular $\mathrm{Pd}_{6} \mathrm{~L}_{12}$ Aggregate. Angew. Chem., Int. Ed. 2018, 57, 1217112175.

(31) Nakamura, T.; Ube, H.; Shiro, M.; Shionoya, M. A SelfAssembled Multiporphyrin Cage Complex through Three Different Zinc(II) Center Formation under Well-Balanced Aqueous Conditions. Angew. Chem., Int. Ed. 2013, 52, 720-723.

(32) Chen, B.; Horiuchi, S.; Holstein, J. J.; Tessarolo, J.; Clever, G. $\mathrm{H}$. Tunable Fullerene Affinity of Cages, Bowls and Rings Assembled by Pd(II) Coordination Sphere Engineering. Chem. - Eur. J. 2019, 25, 14921-14927.

(33) Chen, B.; Holstein, J. J.; Horiuchi, S.; Hiller, W. G.; Clever, G. H. Pd(II) Coordination Sphere Engineering: Pyridine Cages, Quinoline Bowls, and Heteroleptic Pills Binding One or Two Fullerenes. J. Am. Chem. Soc. 2019, 141, 8907-8913.

(34) Lewis, J. E. M.; Tarzia, A.; White, A. J. P.; Jelfs, K. E. Conformational Control of $\mathrm{Pd}_{2} \mathrm{~L}_{4}$ Assemblies with Unsymmetrical Ligands. Chem. Sci. 2020, 11, 677-683.

(35) Ogata, D.; Yuasa, J. Dynamic Open Coordination Cage from Non-Symmetrical Imidazole-Pyridine Ditopic Ligands for Turn-On/ Off Anion Binding. Angew. Chem., Int. Ed. 2019, 58, 18424-18428.

(36) Lewis, J.; Crowley, J. Metallo-Supramolecular Self-Assembly with Reduced Symmetry Ligands. ChemPlusChem 2020, 85, 815-827.

(37) Samantray, S.; Krishnaswamy, S.; Chand, D. K. Self-Assembled Conjoined-Cages. Nat. Commun. 2020, 11, 880-891.

(38) Suzuki, K.; Kawano, M.; Fujita, M. Solvato-Controlled Assembly of $\mathrm{Pd}_{3} \mathrm{~L}_{6}$ and $\mathrm{Pd}_{4} \mathrm{~L}_{8}$ Coordination "Boxes. Angew. Chem., Int. Ed. 2007, 46, 2819-2822.

(39) Frank, M.; Johnstone, M. D.; Clever, G. H. Interpenetrated Cage Structures. Chem. - Eur. J. 2016, 22, 14104-14125.

(40) Schulte, T. R.; Holstein, J. J.; Schneider, L.; Adam, A.; Haberhauer, G.; Clever, G. H. A New Mechanically-Interlocked $\left[\mathrm{Pd}_{2} \mathrm{~L}_{4}\right]$ Cage Motif by Dimerization of Two Peptide-based Lemniscates. Angew. Chem., Int. Ed. 2020, 59, 22489-22493.

(41) Chand, D. K.; Biradha, K.; Kawano, M.; Sakamoto, S.; Yamaguchi, K.; Fujita, M. Dynamic Self-Assembly of an $\mathrm{M}_{3} \mathrm{~L}_{6}$ Molecular Triangle and an $\mathrm{M}_{4} \mathrm{~L}_{8}$ Tetrahedron from Naked $\mathrm{Pd}^{\mathrm{II}}$ Ions and Bis(3-pyridyl)-Substituted Arenes. Chem. - Asian J. 2006, 1, 82-90.

(42) Tateishi, T.; Kojima, T.; Hiraoka, S. Multiple Pathways in the Self-Assembly Process of a $\mathrm{Pd}_{4} \mathrm{~L}_{8}$ Coordination Tetrahedron. Inorg. Chem. 2018, 57, 2686-2694.

(43) Klein, C.; Gütz, C.; Bogner, M.; Topić, F.; Rissanen, K.; Lützen, A. A New Structural Motif for an Enantiomerically Pure Metallosupramolecular $\mathrm{Pd}_{4} \mathrm{~L}_{8}$ Aggregate by Anion Templating. Angew. Chem., Int. Ed. 2014, 53, 3739-3742.

(44) Bloch, W. M.; Clever, G. H. Integrative Self-Sorting of Coordination Cages Based on 'Naked' Metal Ions. Chem. Commun. 2017, 53, 8506-8516.

(45) Preston, D.; Barnsley, J. E.; Gordon, K. C.; Crowley, J. D. Controlled Formation of Heteroleptic $\left[\mathrm{Pd}_{2}\left(\mathrm{~L}_{\mathrm{a}}\right)_{2}\left(\mathrm{~L}_{\mathrm{b}}\right)_{2}\right]^{4+}$ Cages. J. Am. Chem. Soc. 2016, 138, 10578-10585.

(46) Yamashina, M.; Yuki, T.; Sei, Y.; Akita, M.; Yoshizawa, M. Anisotropic Expansion of an $\mathrm{M}_{2} \mathrm{~L}_{4}$ Coordination Capsule: Host Capability and Frame Rearrangement. Chem. - Eur. J. 2015, 21, 42004204.

(47) Li, J.-R.; Zhou, H.-C. Bridging-Ligand-Substitution Strategy for the Preparation of Metal-Organic Polyhedra. Nat. Chem. 2010, 2, 893-898.

(48) Sun, Q.; Sato, S.; Fujita, M. An $\mathrm{M}_{12}(\mathrm{~L} 1)_{12}(\mathrm{~L} 2)_{12}$ Cantellated Tetrahedron: A Case Study on Mixed-Ligand Self-Assembly. Angew. Chem., Int. Ed. 2014, 53, 13510-13513.

(49) Bloch, W. M.; Abe, Y.; Holstein, J. J.; Wandtke, C. M.; Dittrich, B.; Clever, G. H. Geometric Complementarity in Assembly and Guest
Recognition of a Bent Heteroleptic cis- $\left[\mathrm{Pd}_{2} \mathrm{~L}_{2}^{\mathrm{A}} \mathrm{L}_{2}^{\mathrm{B}}\right]$ Coordination Cage. J. Am. Chem. Soc. 2016, 138, 13750-13755.

(50) Bloch, W. M.; Holstein, J. J.; Hiller, W.; Clever, G. H. Morphological Control of Heteroleptic cis- and trans $-\mathrm{Pd}_{2} \mathrm{~L}_{2} \mathrm{~L}_{2}{ }_{2}$ Cages. Angew. Chem., Int. Ed. 2017, 56, 8285-8289.

(51) Howlader, P.; Das, P.; Zangrando, E.; Mukherjee, P. S. UreaFunctionalized Self-Assembled Mo-lecular Prism for Heterogeneous Catalysis in Water. J. Am. Chem. Soc. 2016, 138, 1668-1676.

(52) Mukherjee, S.; Mukherjee, P. S. Template-Free Multicomponent Coordination-Driven Self-Assembly of $\mathrm{Pd}(\mathrm{II}) / \mathrm{Pt}(\mathrm{II})$ Molecular Cages. Chem. Commun. 2014, 50, 2239-2248.

(53) Samanta, D.; Shanmugaraju, S.; Joshi, S. A.; Patil, Y. P.; Nethaji, M.; Mukherjee, P. S. Pillar Height Dependent Formation of Unprecedented $\mathrm{Pd}_{8}$ Molecular Swing and $\mathrm{Pd}_{6}$ Molecular Boat via Multicomponent Self-Assembly. Chem. Commun. 2012, 48, 22982300

(54) Wu, K.; Zhang, B.; Drechsler, C.; Holstein, J. J.; Clever, G. H. Backbone-Bridging Promotes Diversity in Heteroleptic Cages. Angew. Chem., Int. Ed. 2021, 60, 6403-6407.

(55) Wise, M. D.; Holstein, J. J.; Pattison, P.; Besnard, C.; Solari, E.; Scopelliti, R.; Bricogne, G.; Severin, K. Large, Heterometallic Coordination Cages Based on Ditopic Metallo-Ligands with 3-Pyridyl Donor Groups. Chem. Sci. 2015, 6, 1004-1010.

(56) Komine, S.; Tateishi, T.; Kojima, T.; Nakagawa, H.; Hayashi, Y.; Takahashi, S.; Hiraoka, S. Self-Assembly Processes of OctahedronShaped $\mathrm{Pd}_{6} \mathrm{~L}_{12}$ Cages. Dalton Trans 2019, 48, 4139-4148.

(57) Bogie, P. M.; Holloway, L. R.; Lyon, Y.; Onishi, N. C.; Beran, G. J. O.; Julian, R. R.; Hooley, R. J. A Springloaded Metal-Ligand Mesocate Allows Access to Trapped Intermediates of Self-Assembly. Inorg. Chem. 2018, 57, 4155-4163.

(58) Young, M. C.; Holloway, L. R.; Johnson, A. M.; Hooley, R. J. A Supramolecular Sorting Hat: Stereocontrol in Metal-Ligand SelfAssembly by Complementary Hydrogen Bonding. Angew. Chem., Int. Ed. 2014, 53, 9832-9836.

(59) Miller, T. F.; Holloway, L. R.; Nye, P. P.; Lyon, Y.; Beran, G. J. O.; Harman, W. H.; Julian, R. R.; Hooley, R. J. Small Structural Variations Have Large Effects on the Assembly Properties and Spin State of Room Temperature High Spin Fe(II) Iminopyridine Cages. Inorg. Chem. 2018, 57, 13386-13396.

(60) Holloway, L. R.; Bogie, P. M.; Lyon, Y.; Julian, R. R.; Hooley, R. J. Stereoselective Postassembly CH Oxidation of Self-Assembled Metal-Ligand Cage Complexes. Inorg. Chem. 2017, 56, 1143511442 .

(61) Zhang, H.-N.; Lin, Y.-J.; Jin, G.-X. Selective Construction of Very Large Stacking-Interaction-Induced Molecular $8_{18}$ Metalla-Knots and Borromean Ring Using Curved Dipyridyl Ligands. J. Am. Chem. Soc. 2021, 143, 1119-1125.

(62) Lewis, J. E. M.; Elliott, A. B. S.; McAdam, C. J.; Gordon, K. C.; Crowley, J. D. 'Click' to Functionalise: Synthesis, Characterisation and Enhancement of the Physical Properties of a Series of Exo - and Endo -Functionalised $\mathrm{Pd}_{2} \mathrm{~L}_{4}$ Nanocages. Chem. Sci. 2014, 5, 18331843.

(63) Elliott, A. B. S.; Lewis, J. E. M.; van der Salm, H.; McAdam, C. J.; Crowley, J. D.; Gordon, K. C. Luminescent Cages: Pendant Emissive Units on $\left[\mathrm{Pd}_{2} \mathrm{~L}_{4}\right]^{4+}$ "Click" Cages. Inorg. Chem. 2016, 55, 3440-3447.

(64) Martir, D. R.; Cordes, D. B.; Slawin, A. M. Z.; Escudero, D.; Jacquemin, D.; Warriner, S. L.; Zysman-Colman, E. A Luminescent $\left[\mathrm{Pd}_{4} \mathrm{Ru}_{8}\right]^{24+}$ Supramolecular Cage. Chem. Commun. 2018, 54, 60166019.

(65) Schmidt, A.; Hollering, M.; Han, J.; Casini, A.; Kühn, F. E. SelfAssembly of Highly Luminescent Heteronuclear Coordination Cages. Dalton Trans 2016, 45, 12297-12300.

\section{NOTE ADDED AFTER ISSUE PUBLICATION}

This article was initially published with an incorrect copyright statement and was corrected on or around May 28, 2021. 